FORUM

\title{
An anthropological contribution to rethinking the relationship between money, debt, and economic growth
}

\author{
Richard H. Robbins
}

\begin{abstract}
Interrelationships among money, debt, and economic growth create a financial system that provides a steady stream of income to banks and private investors-the proverbial 1 percent. However, because economists obscure these interrelationships, threats to the maintenance of the monetary streams of the elite are underreported. Consequently, increasing shares of national incomes must be appropriated to maintain those streams. This article reexamines the nature of and relationships among money, debt, and economic growth to understand austerity programs and why rates of economic growth must decline and how governments and elites adjust to this reality. It then suggests alternative ways of addressing the creation of money and the problems arising from the division of society into net debtors and net creditors.
\end{abstract}

Keywords: austerity, debt, finance, financialization, money, neoliberalism

"Before there was money, there was debt. Before there was an American republic, there was America's national debt. Over the last three decades, the neoliberal reordering of political economy produced a 'debtor nation,' a 'republic of debtors', and an 'American way of debt' resting on a hypertrophied financial system."

- Tayyad Mahmud (2013: 2)

"As the financial system continues to seek new income streams to increase profitability, daily life becomes more and more reflective of the processes by which every day assets are divided up and traded."

$$
\text { - Richard Glover (2010: 5) }
$$

Critically examining the major premises of policy disciplines such as economics should be a major goal of anthropology. Often, concepts that are essential in those disciplines are uncritically accepted, whereas a historical or cross-cultural perspective and the work of anthropology can help reframe the concepts and hence illuminate solutions to social and economic problems. For example, three key economic concepts-money, 
debt, and economic growth-have been largely undertheorized by classical economists, which has consequently obscured, unintentionally or otherwise, vulnerabilities in our political economy and seriously distorted economic policy.

To understand our economy, I suggest, we need to return to a grand bargain struck by William III of England in 1694 with a group of London merchants led by Sir William Patterson. The King secured a loan of 1.2 million pounds sterling to support his war with France in exchange for a royal charter to establish the Bank of England. The 8 percent interest on this loan-which was financed with tax payments and which has never been repaid (Graeber 2014) - created a steady stream of income for the Bank that, along with a reserve supply of silver, granted it the right to issue money as interest-bearing debt. It was a momentous bargain that completed the foundation of modern national economies (Wennerlind 2011; see also Di Muzio and Robbins 2016).

First, the bargain institutionalized a means of money creation in which privately owned institutions, largely banks, create money as interest-bearing debt. Second, the grand bargain financialized the national debt, creating a stream of payments to bondholders based primarily on the power of the state to tax its citizens. Third, it set a benchmark for the expected rate of return on capital and served as a model for the creation of thousands more debt-based monetary streams that include home mortgages, credit card and student debt, corporate, government, and municipal bonds, bad debt, artwork, and Latin American baseball players (see, e.g., Schmidt 2010). Fourth, the issuance of debt-based financial instruments locked our economy into a requirement for perpetual and exponential economic growth. That is, since financial institutions create only the principal, without growth the interest, yield, or return on the loans, government securities, and bonds can never be realized. Finally, the grand bargain locked financial institutions and the nation-state into a partnership whose primary goal would be to maintain the debt-based monetary streams and the perpetual economic growth on which they depend. Sir William Patterson, the brainchild behind the Bank of England, quickly recognized the bond between bank and state. As Carl Wennerlind (2011: 111) put it: "Patterson ... linked the success of the Bank with the survival of the new monarch and, even more importantly, England's national security and its long-cherished ideals of property and freedom."

\section{The debate over the creation and origin of money}

Money has been undertheorized by classical economics probably because of its uncritical embrace of the idea that money evolved from barter, an assumption dismissed by David Graeber (2011), among others. If money simply replaces barter as a means of exchange, there would be no problem as one means of exchange (goods for goods) would simply replace another (goods for money). But the theory neglects to examine the consequences of money created as interest-bearing debt by private institutions such as banks. And there is even debate among economists about how banks work.

There are three general theories regarding the role of banks in money creation (see Di Muzio and Robbins 2017; Dodd 2014; Ingham 2004). The first, and most common, assumption is that banks are simply intermediaries between savers and borrowers. However, this theory cannot account for the expansion of the money supply, only its circulation. The second is the fractional reserve theory. Here, banks lend out a percentage greater than actual deposits, keeping some percentage as reserve to accommodate withdrawals. But, like the intermediary theory, it cannot account for the creation of the amount of new money created (Di Muzio and Noble 2017). The only theory that can fully account for the real expansion of the money supply is the credit creation theory (Werner 2014a, 2014b); new money is created when banks make interest-bearing loans to customers regardless of reserves. 
But banks lend only the principal; the interest must be created elsewhere. Thus, the economy must continually grow at a rate related to the average interest and time period of all loans. The fact that banks create money as interest-bearing debt and that other debt-based instruments dominate the financial landscape prompts three questions: First, how much interest are these debt-based monetary streams generating? Second, who is benefiting from these monetary streams? And, finally, what is the rate of growth of the economy necessary to maintain these monetary streams?

\section{The impact of interest payments on the economy}

There are many explanations for the growing income and wealth inequality documented by Thomas Piketty (2014) in Capital in the TwentyFirst Century. Reasons include patterns of inheritance, globalization, and technological and demographic change (see Gordon 2016; Milanovic 2016). But there is nothing noted on the role of money creation and debt, and this is largely because economists have long treated money as a "neutral veil" over the economy that requires little analysis (see Di Muzio and Robbins 2017). It is hardly that. Looking at the role of total interest in the US economy, Figure 1 and Figure 2 show, respectively, the net amount of interest paid in the United States from 1969 to 2015 and the interest paid as a percentage of gross domestic product (GDP) from 1960 to 2015.

In 1969, interest payments amounted to $\$ 126$ billion or a little less than 9 percent of the United States' national income. By 1982, interest payments increased to more than $\$ 1$ trillion, or 30 percent of the national income. Since the early 1980s, the share of national wealth represented by interest has fluctuated between 15 and 31 percent, but since 1980 it has averaged a little over 25 percent of GDP. To illustrate the scale of interest payments, consider that the amount of interest paid each year in the United States has since 1978 exceeded the amount paid in federal income taxes (Figure 3).

As national economies are presently constituted, every economic transaction-whether the purchase of a commodity, a rent or mortgage payment, a meal at a restaurant, or payment for some service-must contain interest on someone's or something's debt (see Creutz

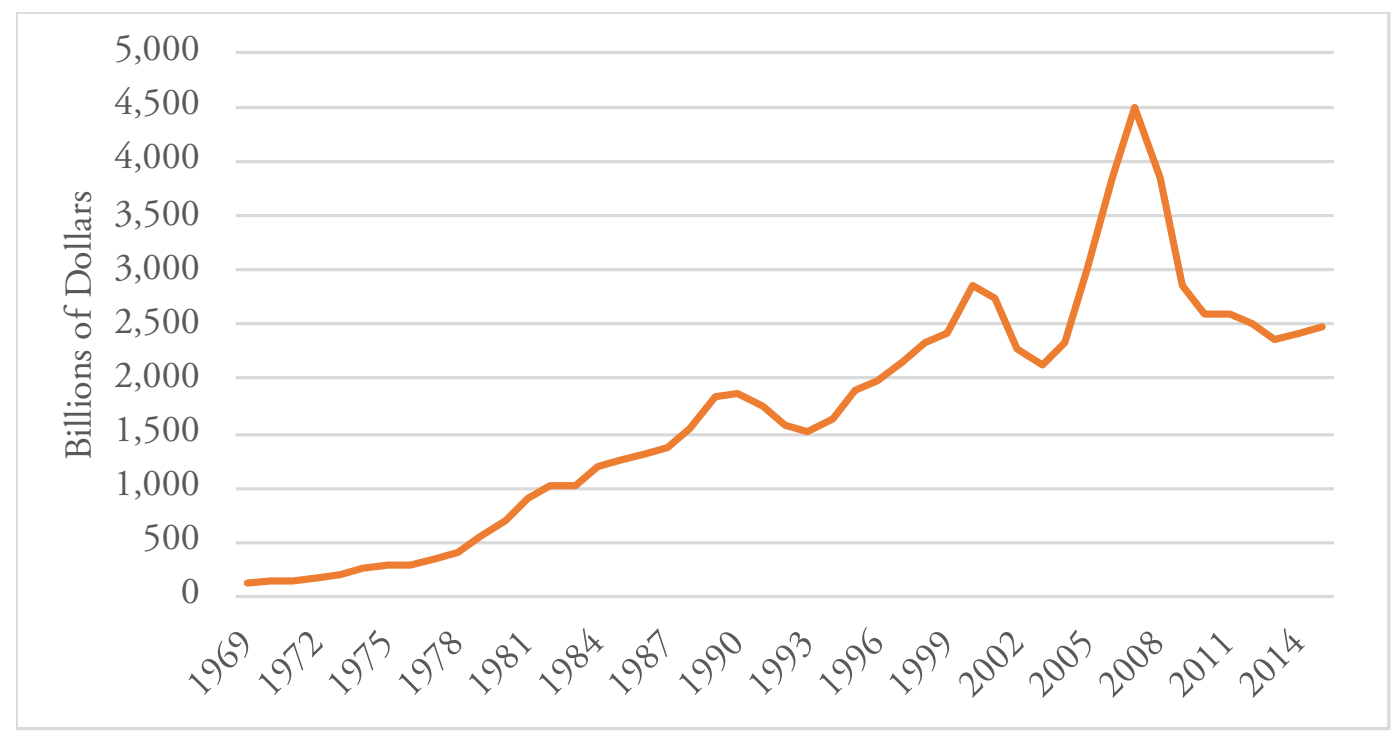

FIgURE 1: US Monetary Interest Paid in Billions (1969-2015)

Source: FRBSTL and OMB (2018) 


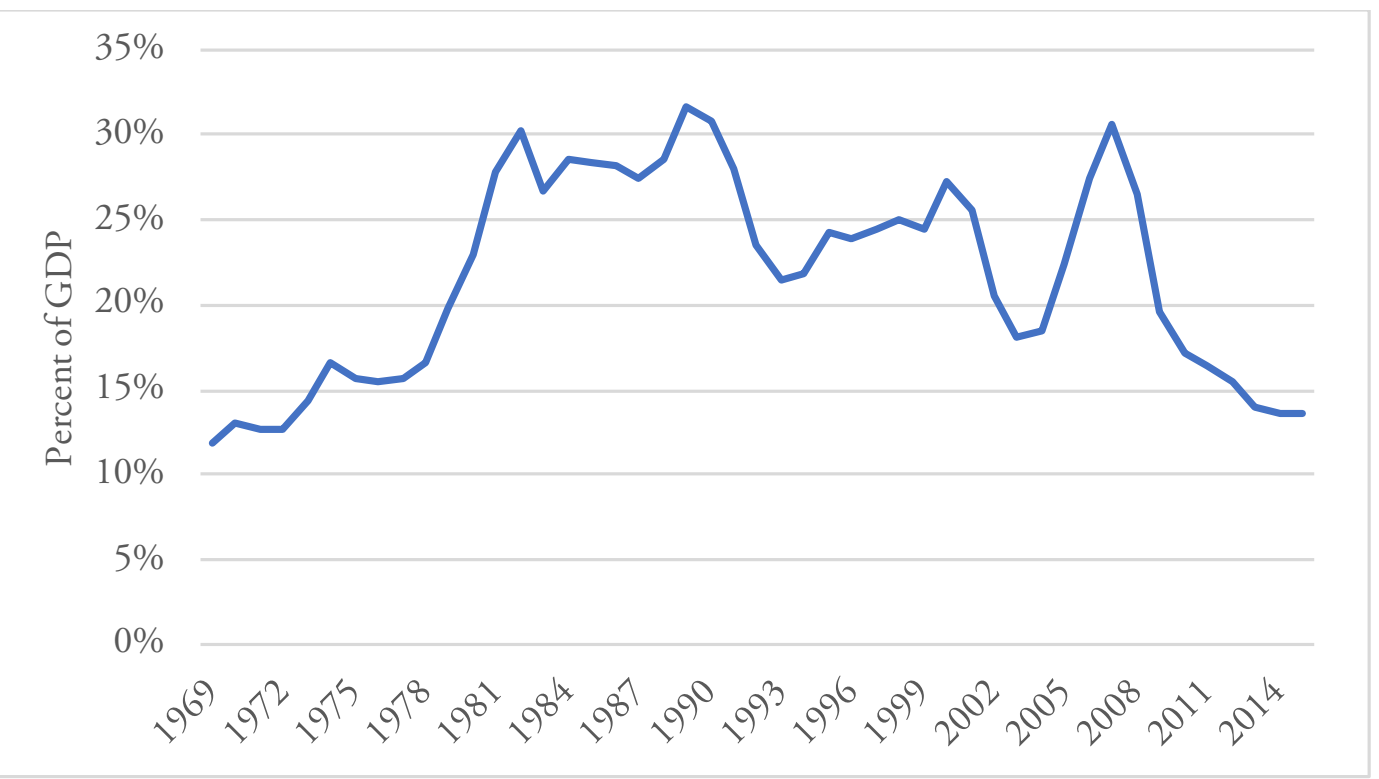

Figure 2: US Monetary Interest Paid as Percent of DGP (1960-2015)

Source: FRBSTL and OMB (2018)

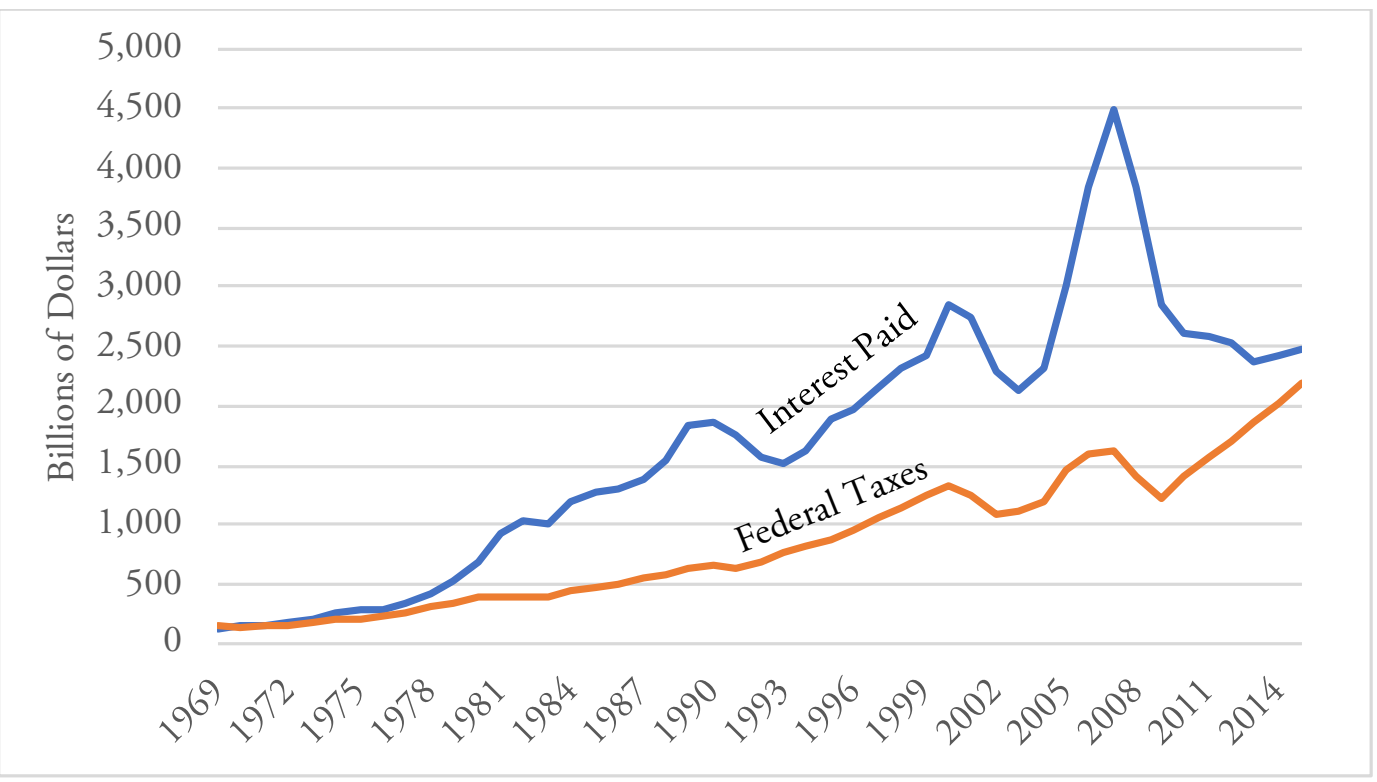

Figure 3: Total Interest Paid in United States Compared to Total Federal Tax Revenue (1969-2015) Sources: BEA 2018a; FRBSTL and OMB (2018)

2010). Even a portion of income and indirect tax payments will go to service the interest on the public debt held by bondholders. Globally, upward of $\$ 2$ trillion yearly flows as interest on only sovereign debt to investors. ${ }^{1}$
To whom do these monetary streams flow? Most of them flow toward those who have the most interest-bearing assets at their disposal (Creutz 2010: 4). Edward Wolff $(2012,2013)$ documents the extent of this wealth transfer. Table 1 
TABLE 1: Total Income-Generating Assets by Percentile of Wealth (2010)

\begin{tabular}{lccc}
\hline Asset Type & $\begin{array}{c}\text { Top } \\
\mathbf{1 \%}\end{array}$ & $\begin{array}{c}\text { Next } \\
\mathbf{9 \%}\end{array}$ & $\begin{array}{c}\text { Bottom } \\
\mathbf{9 0 \%}\end{array}$ \\
\hline Stocks and Mutual Funds & 48.8 & 42.5 & 8.6 \\
Financial Securities & 64.4 & 29.5 & 6.1 \\
Trusts & 38.0 & 43.0 & 19.0 \\
Business Equity & 61.4 & 30.5 & 8.1 \\
Non-Home Real Estate & 35.5 & 43.6 & 20.9 \\
Total Assets for Group & 50.4 & 37.5 & 12.0 \\
Total Debt for Group & 5.9 & 21.6 & 72.5 \\
\hline
\end{tabular}

Source: Wolff $(2012,2013)$

illustrates the distribution of wealth-generating assets by wealth percentile. As one would expect, the top 1 percent has a significantly higher percentage of interest-bearing assets (50.4 percent) and a significantly lower amount of debt (5.9 percent) than the bottom 90 percent (12 percent and 72.5 percent, respectively). While there are various reasons cited for the massive growth in inequality within countries over the past four decades (see Milanovic 2016), the role of interest on debt has been neglected despite the fact that, while other factors may explain gaps in income growth among the larger population, it may be the most likely reason for the income breakaway of the top 1 percent.

In sum, by issuing money as debt-first to the state by central banks and then to private individuals, agencies, firms, and other borrowers-we have created a financial system that provides steady and stable monetary streams to banks and private investors-creditors-that guarantees them a source of power with which to protect their varied interests. The classic division of the economy into labor and capital has been transformed largely into one of net creditors and net debtors (see, e.g., Gerber 2014: 16).

\section{The mystification of economic growth}

In addition to undertheorizing the social and economic consequences of our means of money creation, classical economists have failed to consider the rates that economies must grow in order to generate their debt-based monetary streams. In fact, in the vast literature on economic growth, including two major textbooks (Barro and Salai-Martin 2004; Jones 2002), a Journal of Economic Growth, and a multivolume Handbook of Economic Growth (Aghion and Durlauf 2005), economists have little to offer on why economies must grow or collapse, or on the connections between money, debt, and growth. The only significant treatment of the relationship among these concepts appears in books on the history of sovereign debt (e.g., Ferguson 2002; Greenfeld 2001; Reinhart and Rogoff 2009).

Instead, most economists treat economic growth as a good in itself that requires little justification, an idea reinforced by some linguistic sleight of hand (see, e.g., Friedman 2005). Growth, after all, connotes advancement, expansion, improvement, and, most of all, progress, and contrasts with decline, loss, stagnation, and diminishment. These emotion-packed images obscure the fact that economists are simply describing differential capital accumulation. Consequently, for classical economists perpetual economic growth, as measured by gross national product (GNP), is the source of all well-being and progress (see Korten 1995: 70; Robbins and Dowty 2018). As Michel Foucault put it, for neoliberalism "there is only one true and fundamental social policy: economic growth (2004: 144; see also Arndt 1978).

Only every now and then, a dissenter within the field of economics will take up quality-of-life issues, or question the sustainability of perpetual and exponential economic growth. Even W. Arthur Lewis (1965: 420), in his seminal Theory of Economic Growth, asks whether economic growth is desirable, as have a few others such as Ezra Mishan (1967), Tibor Scitovsky (1976), and, most notably, Herman Daly (1996) in his seminal work Beyond Growth: The Economics of Sustainable Development.

In 2017, US GDP was just over \$18 trillion, or double its size since 1996. Global GDP stood at about $\$ 70$ trillion, more than 20 times what it 
was in 1967. If the US economy grew at the minimum real rate of 3 percent recommended by most economists (close to the growth rate of Japan from 1900 to 2000), US GDP in 2100 would be more than $\$ 200$ trillion, or 600 times what was spent and produced in 1950. And since, as we will see, emerging nations tend to grow at higher rates than wealthy nations, global GDP would approach or exceed a thousand trillion or a quadrillion dollars.

The concept of economic growth needs clarification. What exactly does growth mean, and is it inevitable? Does an increasing GDP really improve people's lives? Most importantly, what kind of insanity would lead us to shrug off the notion of a quadrillion dollar global economy?

\section{What is the necessary rate of growth?}

Despite the lack of a nonideological explanation for the requirement of perpetual and exponential economic growth, most economists, nevertheless, are devoted to data on it (see esp. Barro 1998; Barro and Xavier Sala-i-Martin 2004). This commitment to numbers, however, does not extend to the calculation of the rate of economic growth necessary to maintain the monetary streams generated by total global debt. This should be at least as important as the GDP. ${ }^{2}$

Globally, total debt in the second quarter of 2014 was $\$ 199$ trillion, growing to $\$ 233$ trillion in the third quarter of 2017 (IFF 2018) (see Table 2).
A recent report by McKinsey \& Company (Dobbs et al. 2015) represents one of the few attempts to calculate the necessary growth rates for selected countries to begin to pay down only their sovereign debt (see Table 3). It does not address other categories of debt (e.g., consumer, corporate, municipal, or financial).

Thus, Spain's economy in 2014, growing at 1.7 percent a year, would need to grow an additional 3.8 percent just to begin to pay down its sovereign debt. The United Kingdom's economy, which is projected to grow at 2.5 percent a year (before Brexit), would need to grow at a rate of 4.7 percent a year to begin to honor its government debt.

Since government debt constitutes less than one-third of all global debt, it is not unreasonable to suppose that to pay total debt-that is, to maintain debt-based monetary streams at historic levels would require a growth rate approaching 15 percent a year, a rate not achieved in the United States since 1950.

Furthermore, virtually all recent projections of national and global growth predict a slowing of the rates of growth (see Piketty 2014: 206). In 2016, the IMF (2016) World Economic Outlook report does project global growth to rise to 3.4 percent in 2017. However, it estimates that growth in advanced economies will be 1.6 percent compared to 4.2 percent growth in emerging and developing economies. US GDP growth has continued to slow since 1970 and has not reached three percent for a decade (see Figure 4).

TABLE 2: Global Debt in Trillions

\begin{tabular}{|c|c|c|c|c|c|c|}
\hline \multirow[t]{2}{*}{ Year } & \multicolumn{4}{|c|}{ Types of Debt } & \multirow[t]{2}{*}{ Total } & \multirow[t]{2}{*}{ Debt as a $\%$ of GDP } \\
\hline & Household & Corporate & Government & Financial & & \\
\hline 2000 & 19 & 26 & 22 & 20 & 87 & 246 \\
\hline 2007 & 33 & 38 & 33 & 37 & 142 & 269 \\
\hline 2014 & 40 & 56 & 58 & 45 & 199 & 286 \\
\hline 2017 & - & - & - & - & 233 & 294 \\
\hline$\%$ Increase & & & & & & \\
\hline 2000-2014 & 52 & 54 & 63 & 56 & 56 & 14 \\
\hline
\end{tabular}

Source: Dobbs et al. (2015: 1) 
Table 3: Real GDP Growth Rate to Begin Reducing Public Sector Debt (2014)

\begin{tabular}{|c|c|c|c|c|}
\hline Country & $\begin{array}{l}\text { Growth Rate } \\
\text { Projection } \\
2014-2019^{\star} \\
\end{array}$ & $\begin{array}{l}\text { Additional Growth Rate } \\
\text { Necessary to Begin to } \\
\text { Reduce Public Debt }\end{array}$ & $\begin{array}{l}\text { Total Growth Rate } \\
\text { Required to Begin to } \\
\text { Reduce Public Debt }\end{array}$ & $\begin{array}{c}\text { Government Debt- } \\
\text { to-GDP Ratio }\end{array}$ \\
\hline Spain & 1.7 & 3.8 & 5.5 & 132 \\
\hline United Kingdom & 2.5 & 2.2 & 4.7 & 92 \\
\hline France & 1.5 & 2.5 & 4.0 & 104 \\
\hline Portugal & 1.4 & 2.5 & 3.9 & 148 \\
\hline Finland & 1.6 & 2.1 & 3.6 & 65 \\
\hline United States & 2.8 & 0.3 & 3.1 & 89 \\
\hline Netherlands & 1.6 & 1.3 & 3.0 & 83 \\
\hline Japan & 1.1 & 1.8 & 2.9 & 234 \\
\hline Italy & 0.9 & 1.4 & 2.3 & 139 \\
\hline Belgium & 1.6 & 0.6 & 2.2 & 135 \\
\hline Germany & 1.6 & 0 & 1.6 & 80 \\
\hline
\end{tabular}

* Based on average GDP growth forecasts of the IMF, HIS, Economist Intelligence Unit (EIU), Oxford Economics, the OECD, and the McKinsey Global Growth Model.

Source: Dobbs et al. (2015: 32)

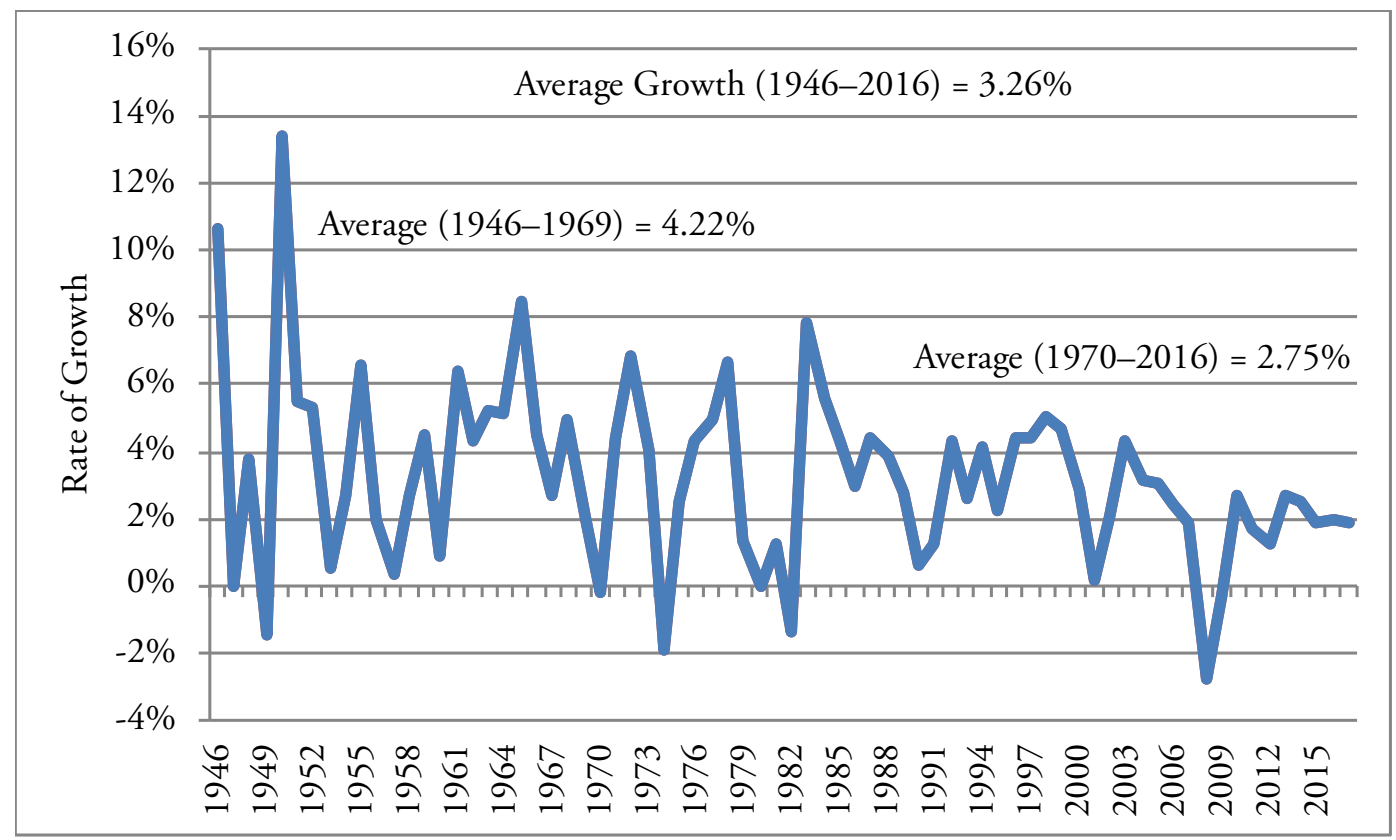

FIGURE 4: US GDP Growth (1947-2016)

Source: BEA (2018b) 
Furthermore, while growth is central to debt repayment, Carmen Reinhart and Kenneth Rogoff (2009: 289) in their study of the past two hundred years of sovereign debt default conclude that countries have never been able to repay their sovereign debt through growth.

Although most projections show a slowing of global economic growth in the near future, most economists still focus on increasing growth. Kaushik Basu (2017), former chief economist at the World Bank, predicts that in 50 years global GDP could be growing by as much as 20 percent a year, doubling every four years or so. Yet economists recognize that as economies become wealthier, it becomes more and more difficult for them to sustain growth. Economists inexplicably call this the convergence factor, noting only that the higher rates of growth in developing countries will eventually "converge" to the lower growth rate of advanced economies (Barro and Xavier Sala-i-Martin 2004: 462-463; Jones 2002: 63-71).

Convergence makes little sense, however, as an explanation for differential growth rates between developing and developed economies; more accurately, the reason for slower growth has to do with the fact that growth must be ex- ponential and that there must be some limit to the creation of profitable new monetary streams.

Take, for example, the lumber industry and the destruction of forests. Between 1990 and 1995, the United States experienced a roughly 3.6 percent increase in trees consumed. However, when we start counting the trees, we see that the percent increase amounted to an increase of about 1.5 million trees cut over the period (Howard 2007). If the same 3.6 percent had been maintained from 2005 to 2010, the number would have been 2.55 million trees. Although we see the same percentage increase in growth, more than one million additional trees were necessarily consumed. The same problem applies to automobiles, as it does any commodity. An increase in production of 2.8 percent from 1997 to 2014 required an increase of 36 million more cars over the period. A 2.8 percent growth rate over the next 18 years would require the production of 58 million more cars.

Second, maintaining a compound rate of growth, as David Harvey (2010: 216) notes, requires capital controllers to find more and more profitable investment opportunities, some 80 percent of which are debt instruments (see Figure 5). For example, of the $\$ 294$ trillion in global

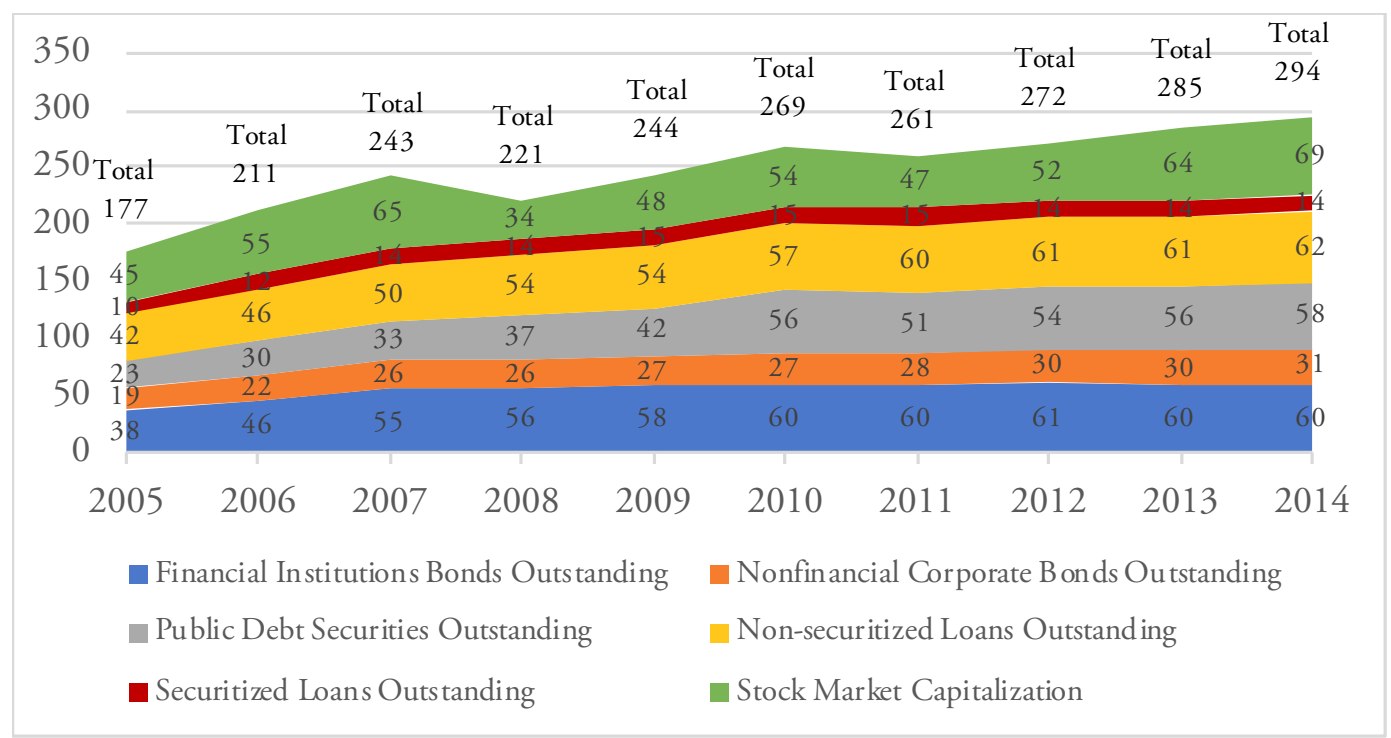

Figure 5: Amount and Type of Global Assets in Trillions (2005-2014)

Source: Ro (2015) 
assets in 2014, more than 75 percent of which are debt-based income streams, almost $\$ 100$ trillion is controlled by institutional investors in pensions and insurance alone, an amount that has more than doubled since 2000 (OECD 2014: 7, 9). Clearly, finding places to invest this increasing amount of money and retain the long-term average of return on capital of from 4 to 6 percent (see Piketty 2014: 206) must become more difficult and, inherently, riskier. Or as the recent IMF Global Financial Stability Report (2017) put it: "The environment of continuing monetary accommodation-necessary to support activity and boost inflation-may lead to a continued search for yield where there is too much money chasing too few yielding assets, pushing investors beyond their traditional habitats."

Harvey (2010: 28) notes that the wave of privatization that is so central to neoliberal policy prescriptions is less about the unproven increases in efficiency and more about finding places to invest money and keep it working and growing. A third problem with maintaining growth is that the more debt we have, the more future income we must channel in order to pay both principle and interest, thus reducing the money we have to spend on goods and services and thus slowing economic growth (Butler 2014).

Finally, as more money seeks a place to grow, competition for viable investments increases their cost, thereby reducing the expected rate of return (Irwin 2014). For investment strategists seeking potential opportunities for clients to realize a decent rate of return relative to risk, the task becomes more difficult. As one investor put it, "If you ask me to give you the one big bargain out there, I'm not sure there is one." Investment advisors are increasingly telling their clients to "lower their expectations" (Dobbs et al. 2016).

\section{If economic growth is slowing, how can investors realize their continuing income streams at the historic 4 to 6 percent?}

If in fact our financial system functions to funnel money and wealth to the proverbial 1 percent, how can their monetary streams be maintained in the face of declining growth and increasing debt? That is, if economic growth is slowing and promises to continually slow for the foreseeable future while debt is rising, as it must if the money available for the economy to grow must also rise, we can conclude that considerable global debt is unpayable (see, e.g., Coggan 2013: 267). If debt cannot be repaid, the power of those whose positions the income streams on debt payments support will be seriously threatened. The question, then, is this: what will their reactions be? Their reactions so far seem to be to take more from "everyone else" and institute ever increasing draconian methods of debt collection.

The fact that the top 1 percent has already succeeded in siphoning off more and more of the national income is evidenced by the growth in income inequality over the past 40 years (see Figure 6 and Figure 7), inequality growth demonstrated by multiple sources led by the work of Thomas Piketty and his colleagues (see, e.g., Piketty 2014).

From 1980 to 2014, the income of the top 1 percent increased by more than 190 percent, the next 19 percent by 70 percent, the middle 60 percent by 46 percent, and the bottom 20 percent by 41 percent (Trisi 2014).

We must first remember that we are focusing on threats to the income of the proverbial 1 percent, or, more accurately, the top .01 to .001 percent. These are the people who control governments, corporations, and, lest we forget, courts, police, and armies (see, e.g., Gilens and Page 2014; Kaiser 2010; Kuhner 2014). It is not unreasonable to suppose that they will use that power, when necessary, to maintain their monetary streams at or near the historical rates of return on capital (see, e.g., Di Muzio 2015).

In effect, what we generally call neoliberalism, austerity, or, in emerging economies, structural adjustment have been, in effect, a series of policies to compensate for slower growth and maintain the benchmark rate of return for the 1 percent.

Neoliberalism (and its twins austerity and structural adjustment) emerged as an approach 


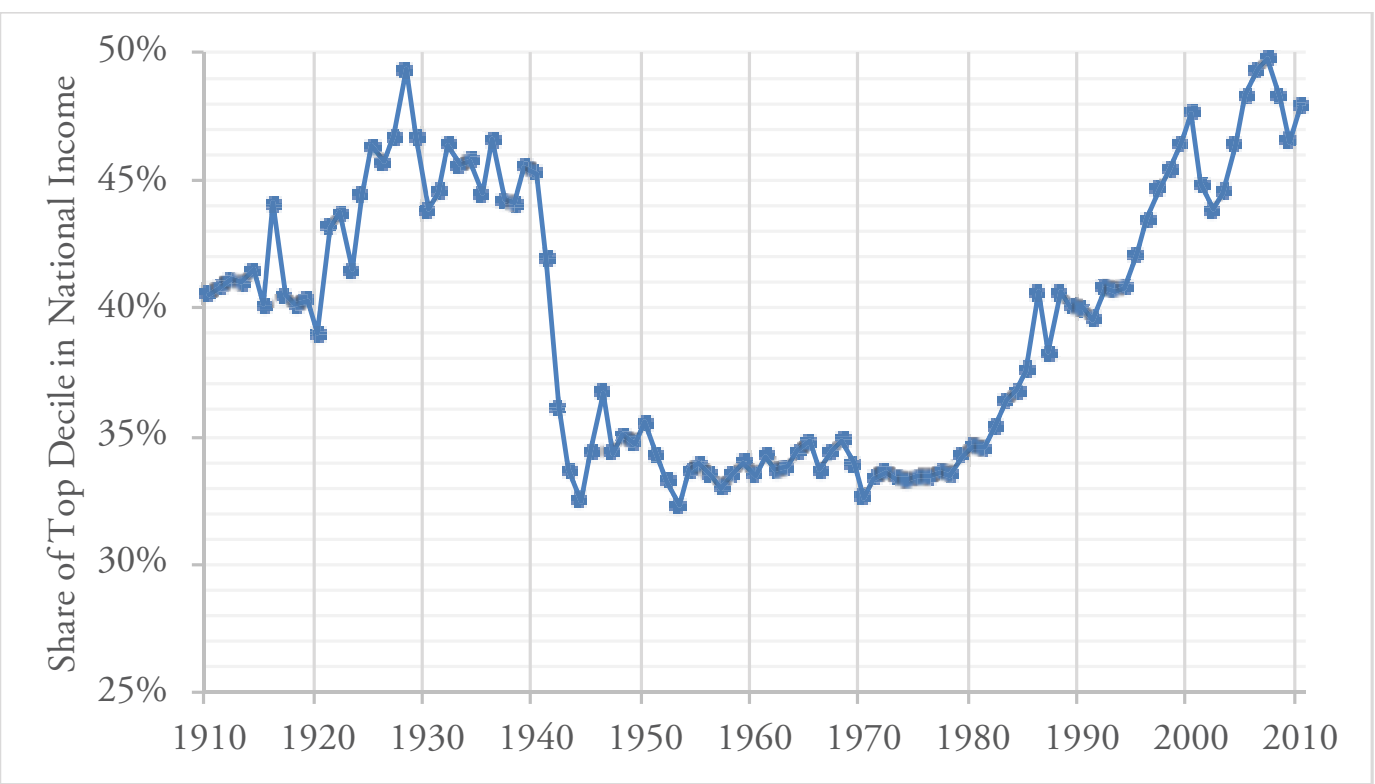

FIGURE 6: Income Inequality in the United States (1910-2010)

Note: The top decile share in US national income dropped from around 45 to 50 percent in the 1910s and 1920s to less than 35 percent in the 1950s (this is the fall documented by Kuznets); it then rose from less than 35 percent in the 1970 s to around 45 to 50 percent in the 2000s and 2010s.

Source: Piketty (2014: 25)

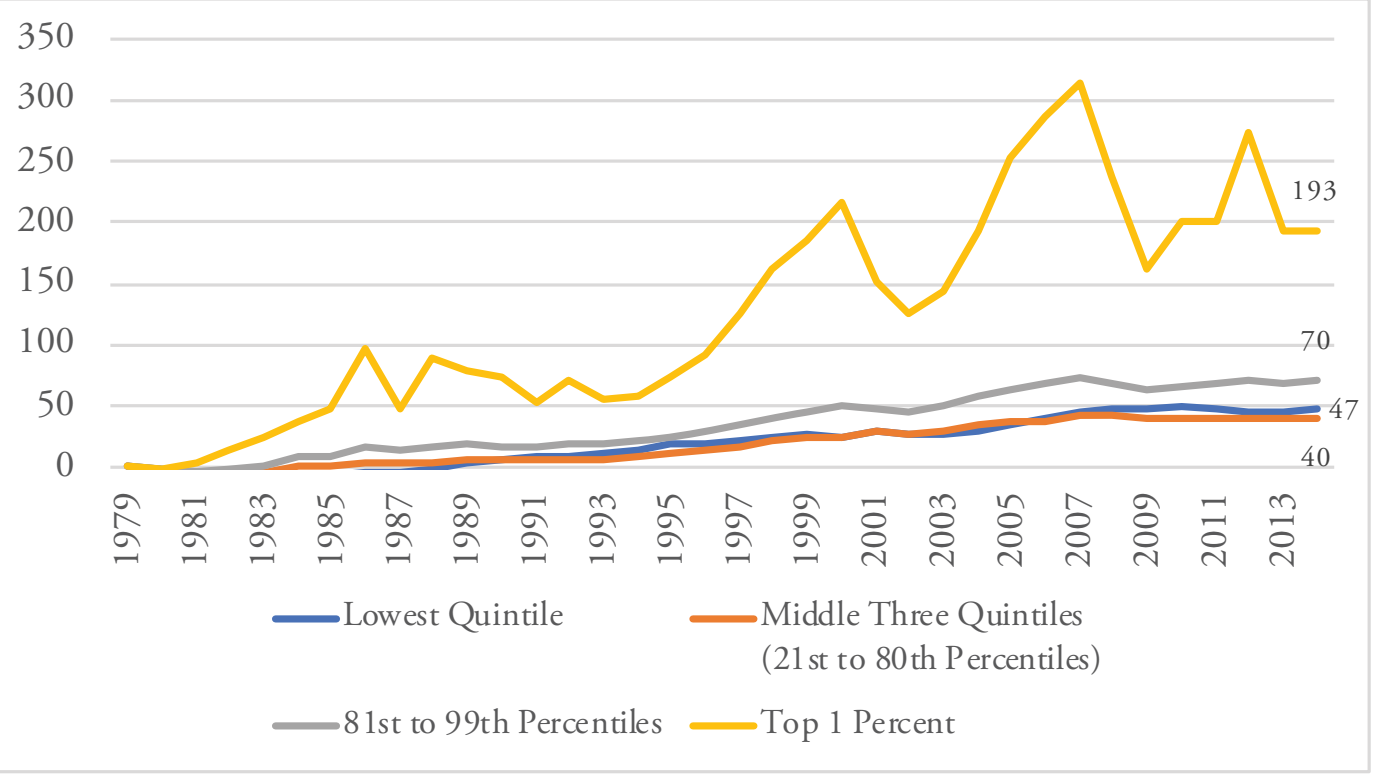

FIgURE 7: Income Distributions by Percentile (1979-2014)

Source: CBO (2014) 
to economic policy in response to the so-called stagflation of the 1970s, which was characterized by high inflation and a lower economic growth rate (see Harvey 2005). Generally, austerity or structural adjustment measures were adopted by or imposed on countries that were somehow defined as delinquent or were said to be "living beyond their means." But this linguistic legerdemain, I maintain, masked the taking by the 1 percent of an increasing share of national income of the 99 percent.

Pavlina Tcherneva (2014) documents the fact that over the past 30 years, when growth returned after an economic downturn, the wealthiest 10 percent, the net creditors, received their money first and, more recently, even confiscated some of the income of the other 90 percent (see Figure 8). As Tcherneva puts it (2014: 54-55):

An examination of average income growth during every postwar expansion (from trough to peak) and its distribution between the wealthiest 10 percent and bottom 90 percent of households reveals that income growth becomes more inequitably distributed with every subsequent expansion during the entire postwar period. Only during the 1950-53 expansion did the bottom 90 percent capture all of the average income growth in the economy. Since then, the top 10 percent of households have been capturing a greater and greater share of the income growth and, in the latest expansion, they have captured over 115 percent of the income growth, while incomes of the bottom 90 percent of households declined.

The "taking" by net creditors of an increasing share of the national income, the "accumulation by dispossession," as Harvey (2004) calls it, reveals the close partnership between the nation-state and the financial elite first evidenced in the grand bargain between the Crown and the Bank of England in 1694. It is only through various legislative initiatives in the United States and elsewhere that the 1 percent are able to preserve their expected rate of return. Here are just a few of these.

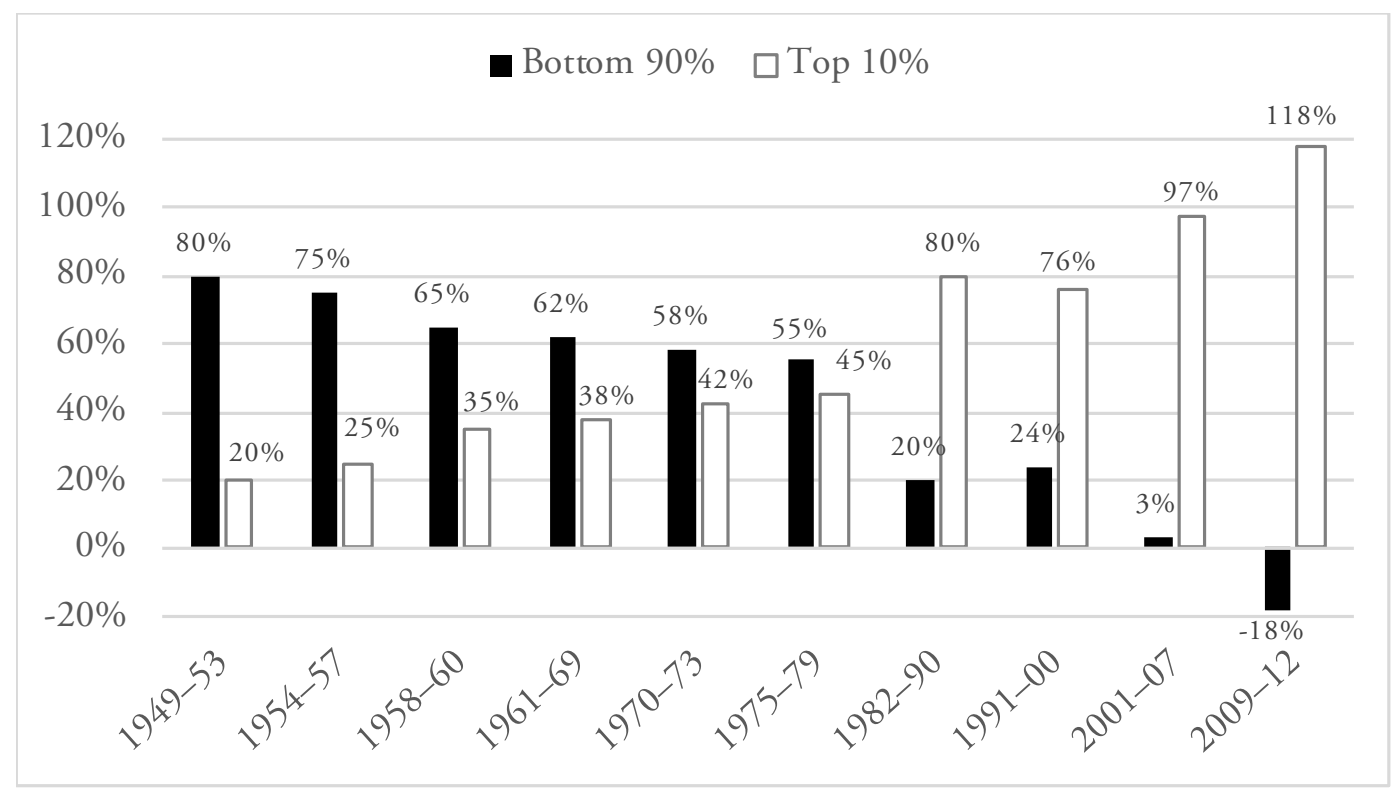

FIgURE 8: Distribution of Average Income during Economic Expansions

Source: Tcherneva (2014) 
First, taxes on the wealthy were reduced. Before 1980, the top tax bracket in the United States was 70 percent, where it had been since the 1930s (see Figure 9). It has since been reduced to between 30 percent and 40 percent (see Noah 2012: 110) and has more recently been reduced to 22 percent.

Second, labor's share of increased capital has been vastly reduced (Figure 10 and Figure 11), such that in real wages it has remained steady or even declined while the share of profits from increased productivity has gone to investors (see Figure 10). Thus, while productivity increased by 73.7 percent from 1973 to 2016 , hourly pay has increased by 12.5 percent.

One way that this redistribution of income was accomplished was by the systematic destruction of workers' unions (see Figure 11). Union membership in the United States has declined from 21 million persons, or 31 percent of the workforce, to 15 million persons, or 12 percent of the workforce, 7 percent if you exclude government employees (Noah 2012: 128). This also increased social inequality and reduced social mobility (see Piketty 2014).
Added to the weakening of the bargaining power of workers is the failure of legislation to adequately raise the minimum wage to keep up with productivity. Had the minimum wage in the United States kept up with worker productivity, as it had until the late 1960s, the minimum wage today would be almost $\$ 22$ per hour (Gordon 2016).

Third, government regulations or enforcement of environmental laws, labor laws, advertising, illegal immigration, and capital flows were eliminated or relaxed. US regulations regarding advertising targeted to children were loosened, promoting a barrage of sophisticated ads targeting kids two years of age and older. Laws aimed at protecting the environment were either gutted or went unenforced (see Speth 2008), while restrictions on banks, such as the Glass-Steagall Act that limited speculative investing by commercial banks, were removed, increasing investment opportunities for the wealthy but exposing the economy to greater risk. And, since the election of President Donald Trump in the United States, regulations in virtually all areas are being further dismantled.

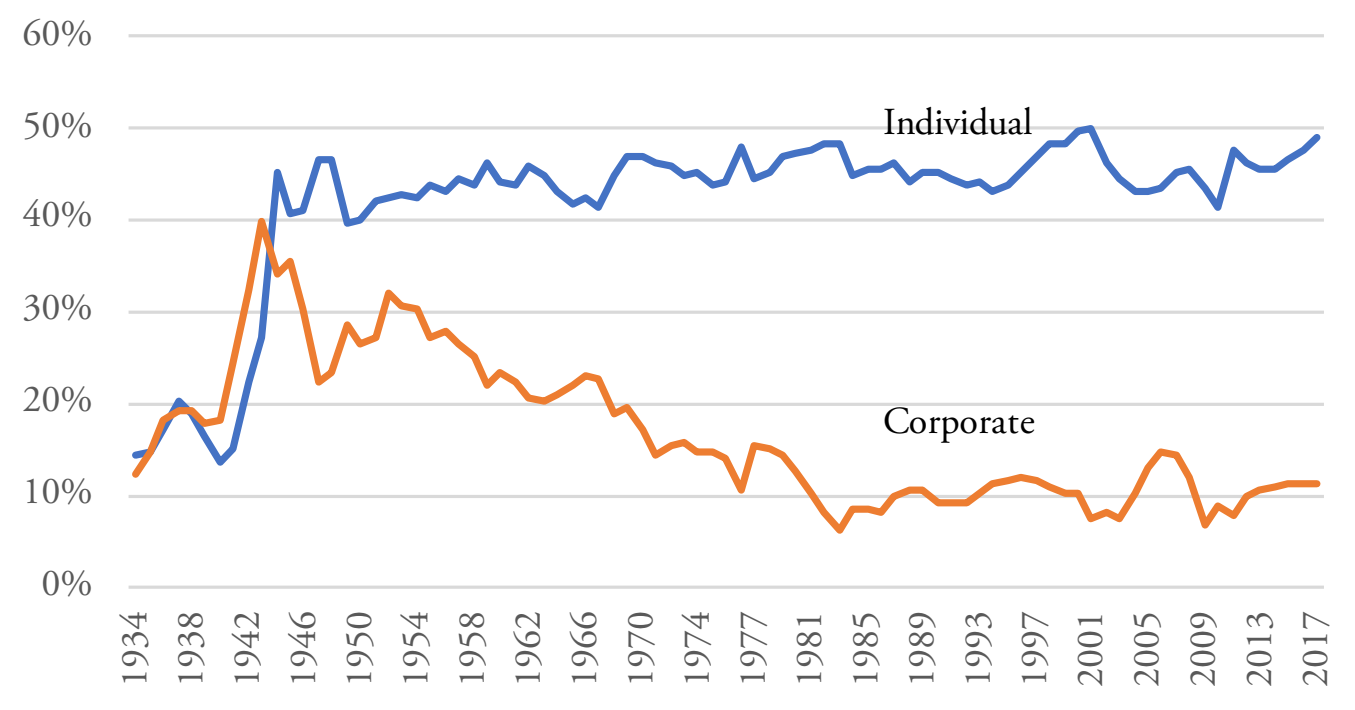

Figure 9: Individual and Corporate Income Taxes as a Percentage of Total Federal Revenue Source: TPC (2017) 


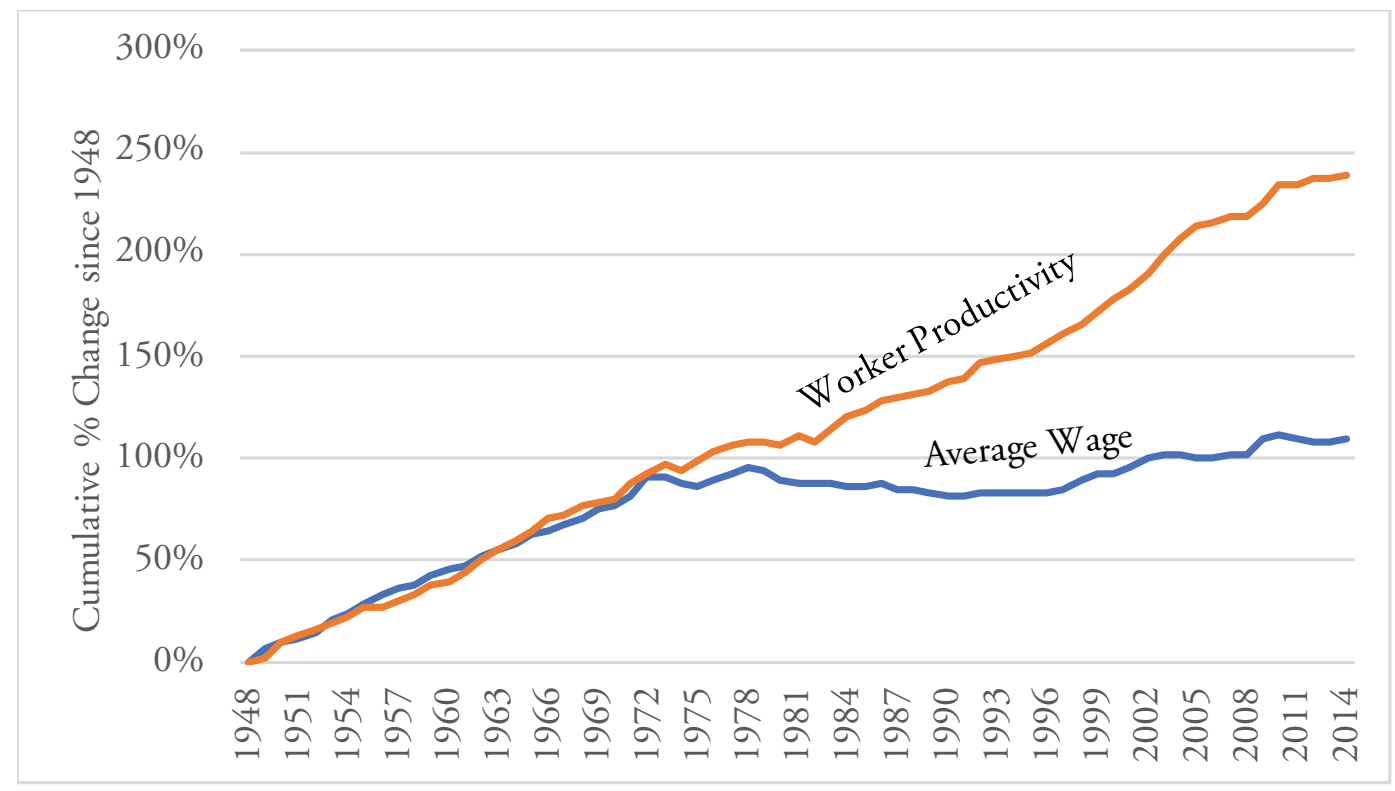

FIgURE 10: Comparison of Worker Productivity and Average Wage in the United States (1948-2014) Source: Bivens and Mishel (2017)

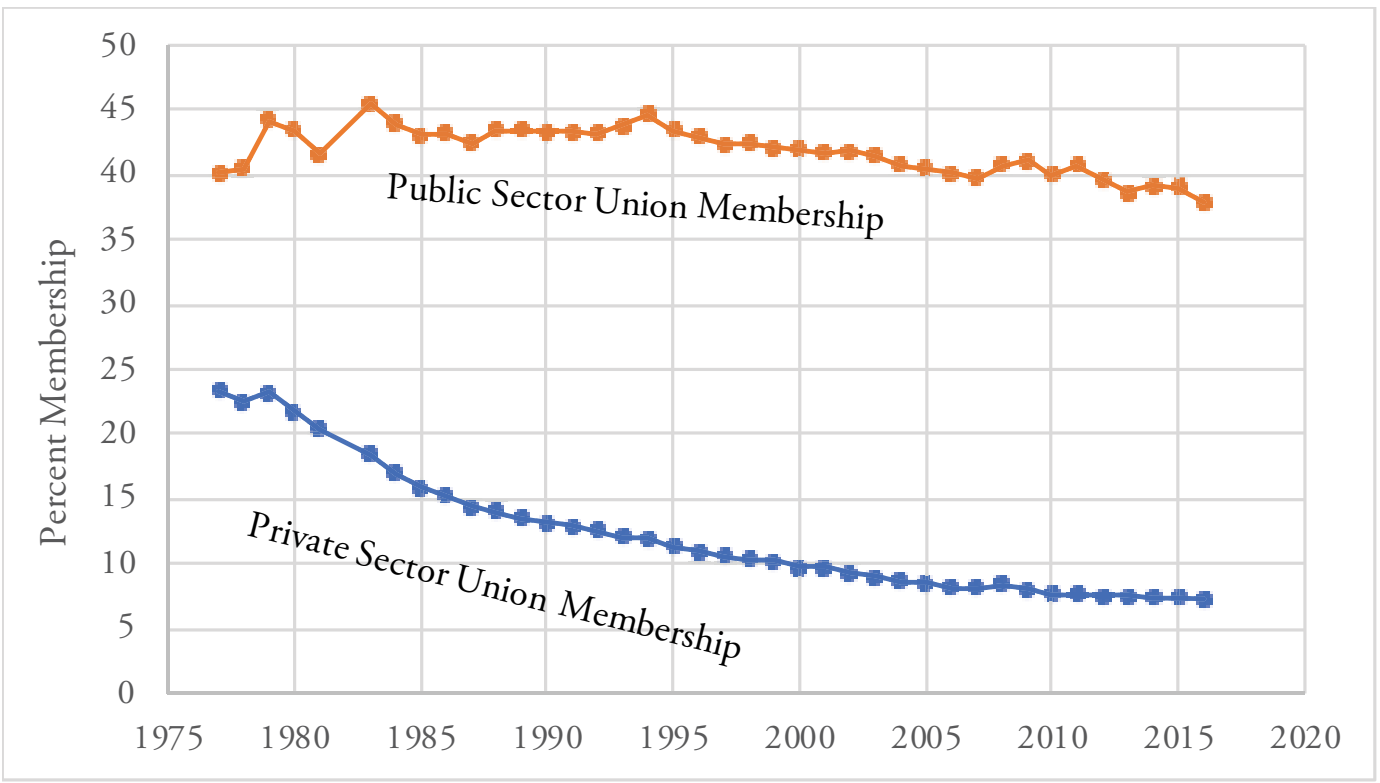

Figure 11: Rate of Public and Private Sector Union Membership in the United States (1977-2016) Source: Unionstat (2017)

Fourth, governments weakened monopoly laws, thus decreasing competition among corporations and keeping prices (and profit) relatively high. The "merger frenzy" of the 1990s is illustrative of the weakening monopoly laws in the United States. One result was to give corporations and financial institutions greater political power and make them "too big to fail."

Fifth, central banks assured the profitability of investments by keeping inflation low. Infla- 
tion reduces the value of currency over time by reducing what you can buy with it. It also cuts into the profits of investors by reducing the value of money received compared to the money that was lent or invested. On the other hand, inflation is desirable for debtors because debts become easier to repay.

Sixth, tax dollars were used to protect or bail out troubled commercial and investment banks (see, e.g., Zepezauer and Naiman 1996). In addition, military spending, 54 percent of all federal discretionary spending in the United States, served as an economic stimulus by funneling money through the armaments and security industry.

Seventh, the so-called safety net was weakened. So-called austerity programs weaken pension plans, assistance to the poor, and programs to assist children in poverty.

Eighth, processes of debt collection have become more draconian and bankruptcy laws stricter. Judicial procedures and the actions of courts increasingly favor creditors. The recent court decision involving Argentina and hedge funds invested in sovereign debt, which said that heavily indebted countries must repay all creditors, equally reduces the possibility of managed debt repayment (Moyer 2016).

Finally, the growth of return on capital was maintained by keeping interest rates low (while bank and investment fees increased), thereby easing credit. Thus, people could borrow more in order to spend and consume in the face of stagnating wages, although to do so required them to go into greater debt. In 2017, household debt exceeded the amount of $\$ 12.73$ trillion just before the economic collapse of 2007-2008 (see Table 4 and Figure 15). This not only allows banks and investors to profit but also increases economic inequality. Increased borrowing also increases the risk of a financial crisis that impacts more heavily on the less rich and that weakens the ability of governments to help those in need. Furthermore, the higher debt load increases the required rate of growth in order for lenders and investors to get their money back with greater value.
TABLE 4: Household Debt in Trillions in the United States by Category (2010, 2012, 2014, 2017)

\begin{tabular}{lcccc}
\hline Category of Debt & 2010 & 2012 & 2014 & 2017 \\
\hline Mortgage & 8.452 & 8.033 & 8.170 & 8.882 \\
Home Equity & & & & \\
Revolving & 0.668 & 0.563 & 0.510 & 0.444 \\
Auto Loan & 0.711 & 0.783 & 0.955 & 1.221 \\
Credit Card & 0.730 & 0.679 & 0.700 & 0.834 \\
Student Loan & 0.812 & 0.966 & 1.157 & 1.378 \\
Other & 0.341 & 0.317 & 0.335 & 0.389 \\
Total & 11.713 & 11.341 & 11.827 & 13.148 \\
\hline
\end{tabular}

Source: FRBNY (2017a)

All of these steps, among others, maintained income flows to investors and creditors despite the inherent difficulty of maintaining the necessary rate of growth, although each, in some way, by taking from everyone else, exposes the majority of persons all over the globe to lower incomes, more hunger and poverty, greater environmental pollution and devastation, greater exposure to disease, and conflict. But as exponential economic growth becomes harder and harder to maintain, so-called neoliberal, austerity, or structural adjustment measures must intensify, thus shifting a continually larger share of national incomes to the 1 percent.

\section{The mystification of debt}

Of the three concepts-money, debt, and economic growth-debt is perhaps the most problematic and in need of demystification by anthropologists. David Graeber (2011) brilliantly begins this task in Debt: The First 5,000 Years, essentially asking, "Why do good people always have to pay their debts?" This is the point of Friedrich Nietzsche's On the Genealogy of Morality (2006), which Graeber critiques. Nietzsche starts with the fact that the word for "guilt" and "sin" in German (Schuld) derives from the word for "debt" (Schulden). Historically, this association begins, says Nietzsche, in 


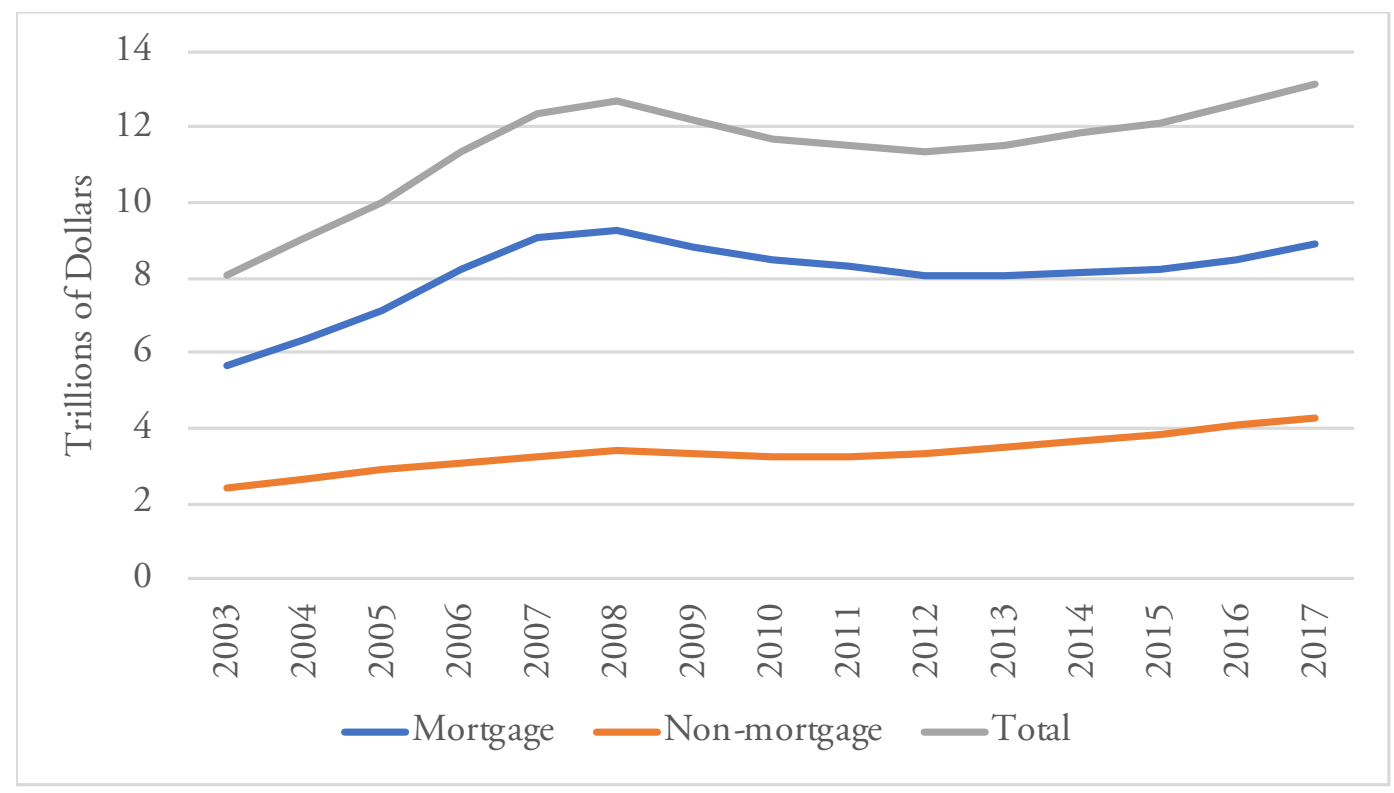

FIGURE 12: Increase in Household Debt in the United States (2004-2017) Source: FRBNY (2017b)

the economic relationship between creditor and debtor, when "person met person for the first time, and measured himself person against person" (2006: 45). Here, the creditor must evaluate not only the investment potential of the loan but also the trustworthiness and character of the debtor. The creditor assumes the position of power over the debtor, while the debtor, in order to redeem their honor, must, above all else, repay the debt, that is, justify the creditor's trust. The seriousness of the obligation, as Graeber notes, is such that in many societies borrowers would pledge family members or themselves as collateral. Debt slavery and trafficking of women today often takes place in the context of debt repayment. The question is why, today, ancient notions of guilt and honor should be associated with modern financial transactions.

While penalties for debt default could be severe before the modern era, default was largely an individual or local issue with little wider significance. That is, the scope of debt was never so great that massive default could threaten the economy of a village, region, or territory. When the tulip bubble burst in Holland in 1637, it was such an unusual event that no mechanism existed for creditors to collect from bankrupt debtors who had borrowed to profit in anticipation of a rise in tulip bulb prices (Vries and Woude 1997: 151). It was not until the English financial revolution and the creation of the Bank of England, when money was issued as interest-bearing debt, that massive default could threaten complete economic collapse.

Thus, not only does debt dominate the modern economy, but, as debt-based income streams support the powers of elites, the relationship between debtor and creditor in reality has changed. Debt was not only inevitable for a normal citizen (if only for tax payments to repay the national debt), but it became the chief product of the banking and financial industry, which either created or controlled global wealth. At this point, the debtor and the monetary streams that the debtor maintained became the foundation of the whole economy, as well as the source of power of elites. Without debtors laboring to earn the interest on the debt and sustain the income streams that flow disproportionately to the few, and above all honor their debts, there 
would be no economy, and, by implication, no 1 percent. Yet the position of the debtor as supplicant and as guilt-laden soul remains; the credit score has become a measure of character and worth, the loan application a process of ritual degradation, while debt collectors are set loose to harass the delinquent. Creditors, on the other hand, are surrounded with symbols of powergreat buildings, ornate offices, and, clearly, the support of the government. It is far easier in modern legislatures to pass measures to tighten up bankruptcy laws or punish debtors than it is to enact laws to protect debtors and consumers.

Thus, our culture embodies in a myriad of ways the power of the creditor over the debtor and the shame, guilt, and sin associated with borrowing. It embodies the dominant idea encapsulated in the phrase, "Surely, one has to pay one's debts." As an example of the moral bankruptcy of our attitude toward debt, Graeber (2011: 4) points to an IMF austerity program that ended a mosquito eradication effort in Madagascar, resulting in a malaria outbreak and the deaths of 10,000 people. Economists James Boyce and Léonce Ndikumana (2011: 83), in their book Africa's Odious Debts, calculate that each dollar in external debt service is associated with a decrease of about $\$ 0.29$ in public health spending. They calculate that this translates into a total of 77,000 unnecessary infant deaths per year in Africa. And there are, of course, thousands of such examples. We need to ask why the repayment of monetary debt, largely to banks and the wealthiest among us, takes precedence over the health of children.? To some extent, David Graeber asked only one key question: it's not just "Why do good people pay their debts?" but, as importantly, "Why do creditors always come first?"

\section{Debt and the bargain of 1694}

To understand why our financial system prioritizes the rights of creditors ahead of infant health and a whole range of societal and individual indices of well-being-food, environmental quality, health, education, shelter, etc.-we must return again to the grand bargain of 1694 .

The establishment of the Bank of England represented a radical solution to the then shortage of money-that is, gold-by essentially substituting paper for gold. But that created a massive new problem centered on the issue of trust. How do you get people to accept paper in place of gold? For the solution to work at the time, investors in government or private debt must have been reassured that (1) they could exchange their paper notes for the promised amount of gold, and that (2) the government or private borrower could (or would) repay their debt. In late seventeenth-century England, the solution to the first problem was solved, after great debate, by the Recoinage Act of 1695, when all coins were recalled and reminted to assure that each coin contained the proper amount of valuable metal, even though it reduced the supply of coins (see Wennerlind 2011: 124-141). To ensure further confidence in the coinage and to combat counterfeiters, the Bank of England recruited Sir Isaac Newton to become the Warden of the Mint and to investigate, detect, and prosecute crimes against the currency, a capital offense (Wennerlind 2011: 126).

The second problem proved more difficult and is still with us. By 1710, England, fighting both France and Spain, borrowed heavily, and holders of government bonds feared that the government would be unable to honor their debt payments. Consequently, the value of bonds began to fall. To restore confidence that government debt, now held by a wide cross-section of English society-ranging from the wealthiest lords to shopkeepers and maids-politicians secured the services of writers such as Daniel Defoe and Jonathan Swift to create pamphlets extolling the wonders of the new financial system and the fortunes to be made. When this failed to completely staunch the fear of bondholders and government debt continued to rise, Lord Treasurer Robert Harley's ingenious solution was to launch the South Sea Company to trade with Spanish colonies largely in African slaves. He then offered holders of government 
debt a swap of their government bonds for Company shares, promising huge profits from the slave trade with Spanish colonies. Within a year, the Company assumed all government debt and investors once again felt secure to lend to the government. Trust in the new system was, at least temporarily, restored, albeit at the cost of African lives.

But the problem of trust, of course, remains the central issue in a debt-based, paper-money regime, arising particularly when threatened with periodic financial collapse. The South Sea Company did collapse leaving creditors and investors mourning their losses, as they did in subsequent depressions and recessions, including the "Great Contraction" of 2007-2008 (see Frazer 2005; Kindleberger 2000; Reinhart and Rogoff 2009). ${ }^{3}$ While trust in debt repayment generally rebounds, it sometimes takes decades to do so. However, the problem of trust, or more properly, "confidence," always remains. Creditors have access to all sorts of devices to ensure confidence, trust, and the security in their investments, including variable interest rates, credit scores, and credit ratings, not to mention legislative and judicial support in collecting debts. But arguably, the greatest assurance is the moral rule that "good people always pay their debts," the corollary of which is that "creditors always have priority." Honor, so important in antiquity and in face-to-face communities, remains a key component of our financial system. But the cost is great.

The fact that creditors have first claim on monetary resources is evidenced by the austerity and structural adjustment programs imposed on indebted nations that prioritize debt repayment ahead of food and medical care for children and adults, shelter, the environment, and so on. In other words, a financial transaction, the repayment of a loan (or the maintenance of monetary streams), must take moral priority over the well-being of persons and societies. ${ }^{4}$ If creditors fear that they will not receive their payments, that externalities such as children's health, adequate food, or environmental protections may intervene, they may refuse to lend, in which case the entire economy will freeze up. There is truth to the statement that money is, in modern financial systems where capital is created and controlled largely by private owners, more important than people. Otherwise, the financial system risks permanent collapse.

With the vast portion of global wealth in private hands, and with most of that managed by professional wealth managers whose success requires maximizing the rate of return for clients, it is hardly surprising that nothing-not infants' health, not access to food, not the environment, nothing-be allowed to interfere with that goal. This directive is even explicitly written into general obligation bonds issued by countries so desperate for capital that they promise to pay debt service before all other expenses (see, e.g., Fajgenbaum et al. 2015; and GDB 2016).

The questions, then, are (1) is such a financial system viable, especially given the rise in debt, the increased difficulty of producing payments, the social backlash from those negatively affected and the expectations of the powerful that their historic rate of return will be maintained always; and (2) is there a way to reprioritize our societal goals? Or to put it another way, what would a society in which people were more important than money or debt repayment look like?

\section{Conclusion}

Looking at our financial system through an anthropological and historical lens reveals that our financial system has historical, social, and political roots. It has and can be changed. To do that, we must revisit the grand bargain of 1694 and the gift to private parties of the right to issue money as interest-bearing debt, hence putting most wealth into private hands.

The rights to create money have shifted back and forth between private and public interests throughout history (Zarlenga 2002). In the United States, public banking can be traced back to the original colonies, when, short of British money and gold with which to trade, 
individual colonies issued their own script that was accepted in trade. Pennsylvania had a state loan office that issued money and collected interest and returned it to the provincial government and used this money in lieu of taxes. In fact, it was the British Currency Acts of 1751 and 1764 that sought to regulate or eliminate colonial script, one of the causes of the American Revolution.

A more recent option for money creation is the "Chicago Plan," named after economists at the University of Chicago who had first proposed it in 1933 (see Di Muzio and Robbins 2017: 112-118). In brief, it forbids banks from lending out more money than they have in reserve, instituting, in effect, a 100 percent reserve rule. Implementation of the Chicago Plan would require the government to issue currency for the purpose of paying all debts, both public and private. Banks would become what most people think they are, simple intermediaries, accepting savings and lending out what they collect (see Kumhof and Benes 2012; Lietaer and Dunne 2013: 70; Phillips 1999).

Another solution gaining increasing attention globally is the creation of public banks. Public banks have much in common with the principles of the Chicago Plan; remove the money-creation function from private interests and assign it to governments, states, or regions (see Brown 2013). The Chicago Plan leaves the function of money creation centralized in the hands of the state, a situation criticized by some as adding to centralized government power (see Lietaer and Dunne 2013: 70). A public banking system, on the other hand, can be highly decentralized with community, regional, or national banks.

The final question, of course, is how, given the political landscape in the United States, Europe, and around the world, along with the influence of money in politics, is it possible to convince legislatures, parliaments, and other government bodies to make such changes?

The key point regarding political action is this: from a political perspective, societies are no longer largely divided into capitalists and laborers. Rather, they are divided largely into creditors and debtors. Consequently, it is only the power of debtors to threaten to withhold their debt payments, as laborers have used their power to withhold their labor, that is capable of negotiating change. Given what is at stake and the direction in which countries all over the world are headed, it is, I believe, the only possible way for people in countries that are ostensibly democracies to make their voices and power heard.

Richard H. Robbins received his $\mathrm{PhD}$ in anthropology from the University of North Carolina at Chapel Hill and has spent his entire teaching career at SUNY Plattsburgh. Recent publications include An Anthropology of Money: A Critical Analysis (2017) and Debt as Power (2016), both with Tim Di Muzio. Other recent works include Global Problems and the Culture of Capitalism (7th ed., 2018) and Cultural Anthropology: A Problem-Based Approach (7th ed., 2016), both with Rachel Dowty. He is the recipient of the American Anthropological Association / Oxford University Press Teacher of the Year Award. He is currently Distinguished Teaching Professor at SUNY Plattsburgh. E-mail: richard.robbins@plattsburgh.edu

\section{Notes}

1. The scope of this interest, of course, runs into the trillions of dollars. Yearly interest payments to sovereign bondholders alone in 2015, globally, is more than $\$ 2$ trillion dollars (see WBG 2018).

2. The absence of a measure of the rate of growth necessary for income streams to be maintained allows economists and policy makers to assume that an accepted rate of growth is about 3 percent, far lower than needed. It assumes also that anything much above that level is harmful, since it leads to a rise in prices (inflation). To justify "cooling" the economy by raising interest rates and slowing growth, economists require the empirically impoverished concept of "natural 
rate of unemployment," generally put at 4.7 to 5.8 percent. If nothing else, the continued mystification of economic growth requires millions of unemployed workers.

3. The fact that the rate of growth necessary to pay off all debts is not included in the economist's repertoire of numbers may have to do with the issue of investor confidence. If investors lose confidence in the ability of growth to realize the monetary stream expected, they may either refuse to invest or they may demand a higher return to account for the increased risk. This was the same problem that confronted England during the early stages of its financial revolution, when declines in returns led to claims that credit was unreliable, which resulted in declining confidence and further falls in bond and security prices (see Wennerlind 2011: 161-196).

4. The present success of Bitcoin and other digital currency is owed, at least part, to the trust engendered by totally eliminating any intermediary subject to human decision making (e.g., governments, banks, etc.) from the financial transaction. You only need, theoretically, to trust the technology of the computer network.

\section{References}

Aghion, Philippe, and Steven N. Durlauf. 2005. Handbook of economic growth. North-Holland: Elsevier.

Arndt, Heinz Wolfgang. 1978. The rise and fall of economic growth: A study in contemporary thought. Chicago: University of Chicago Press.

Bajpai, Prableen. 2014. "The biggest mergers and acquisitions in the U.S." Navarino Investment (blog), 27 October. https://navarinoinvestment .blogspot.com/2014/10/the-biggest-mergersacquisitions-in-us.html.

Barro, Robert J. 1998. The determinants of economic growth. Cambridge, MA: MIT Press.

Barro, Robert J., and Xavier Sala-i-Martin. 2004. Economic growth. 2nd ed. Cambridge, MA: MIT Press.

Basu, Kaushik. 2017. "The global economy in 2067." Project Syndicate, 21 June. https://www.projectsyndicate.org/commentary/long-term-globaleconomic-prospects-by-kaushik-basu-2017-06.

BEA (Bureau of Economic Analysis). 2018a. "Federal government current tax receipts [W006RC-
1Q027SBEA]." FRED, Federal Reserve Bank of St. Louis, accessed 2 April. https://fred.stlouisfed .org/series/W006RC1Q027SBEA.

BEA (Bureau of Economic Analysis). 2018b. "Gross domestic product (GDP)." FRED, Federal Reserve Bank of St. Louis, accessed 2 April. https:// fred.stlouisfed.org/series/GDP.

Bivens, Josh, and Lawrence Mishel. 2017. "Understanding the historic divergence between productivity and a typical worker's pay: Why it matters and why it's real." EPI Briefing Paper no. 406. Washington, DC: Economic Policy Institute. http://www.epi.org/publication/understandingthe-historic-divergence-between-productivityand-a-typical-workers-pay-why-it-matters-andwhy-its-real.

Boyce, James K., and Leonce Ndikumana. 2011. Africa's odious debts: How foreign loans and capital flight bled a continent. London: Zed Books.

Brown, Ellen Hodgson. 2013. The public bank solution: From austerity to prosperity. Ithaca, NY: Third Millennium Press.

Butler, James. 2014. "What the total U.S. debt really looks like and what it all means." Independent Voter Network, 11 June. http://ivn .us/2014/06/11/what-is-the-real-us-total-debt.

$\mathrm{CBO}$ (Congressional Budget Office). 2014. The distribution of household income, 2014. Washington, DC: CBO. https://www.cbo.gov/ publication/53597.

Coggan, Philip. 2013. Paper promises: Debt, money, and the new world order. New York: Public Affairs.

Creutz, Helmut. 2010. The money syndrome. London: Upfront Publishing.

Daly, Herman. 1996. Beyond growth: The economics of sustainable development. Boston: Beacon Press.

Di Muzio, Tim. 2015. The 1\% and the rest of us: $A$ political economy of dominant ownership. London: Zed Books.

Di Muzio, Tim, and Leoni Noble. 2017. "The coming revolution in political economy: Money creation, Mankiw and misguided macroeconomics." Real-World Economics Review 80: 85-108.

Di Muzio, Tim, and Richard H. Robbins. 2016. Debt as power. Manchester: Manchester University Press.

Di Muzio, Tim, and Richard H. Robbins. 2017. An anthropology of money: A critical appraisal. London: Routledge. 
Dobbs, Richard, Susan Lund, Jonathan Woetzel, and Mina Mutafchieva. 2015. Debt and (not much) deleveraging. New York: McKinsey \& Company. https://www.mckinsey.com/global-themes/ employment-and-growth/debt-and-not-muchdeleveraging.

Dobbs, Richard, Susan Lund, Sree Ramaswamy, Joh Harris, and Kekala Krishnan. 2016. Why investors may need to lower their sights. New York: McKinsey \& Company. https://www .mckinsey.com/industries/private-equityand-principal-investors/our-insights/whyinvestors-may-need-to-lower-their-sights.

Dodd, Nigel. 2014. The social life of money. Princeton, NJ: Princeton University Press.

Fajgenbaum, Jose, Jorge Guzman, and Claudio Loser. 2015. "For Puerto Rico, there is a better way: A second look at the commonwealth's finances and options going forward." Washington, DC: Centennial Group. http://www.centennialgroup.com/downloads/For\%20Puerto\%20Rico \%20There\%20is\%20a\%20Better\%20Way.pdf.

Ferguson, Niall. 2002. The cash nexus: Money and power in the modern world, 1700-2000. New York: Basic Books.

Foucault, Michel. 2004. The birth of biopolitics: Lectures at the College de France. London: Picador.

Frazer, Steve. 2005. Every man a speculator: A history of Wall Street in American life. New York: Harper.

FRBNY (Federal Reserve Bank of New York). 2017a. "Household debt and credit report." 31 December. https://www.newyorkfed.org/microeconom ics/databank.html.

FRBNY (Federal Reserve Bank of New York). 2017b. "Household debt surpasses its peak reached during the recession in 2008." Press release, 17 May. https://www.newyorkfed.org/newsevents/ news/research/2017/rp170517.

FRBSTL (Federal Reserve Bank of St. Louis) and OMB (Office of Management and Budget). 2018. "Federal outlays: Interest as percent of gross domestic product [FYOIGDA188S]." FRED, Federal Reserve Bank of St. Louis, accessed 2 April. https://fred.stlouisfed.org/series/FYOIGDA188S.

Friedman, Benjamin. 2005. The morality of economic growth. Cambridge, MA: Harvard University Press.

GDB (Government Development Bank for Puerto Rico). 2016. "Commonwealth of Puerto Rico."
Last updated 18 December. http://www.gdb.pr .gov/investors_resources/commonwealth.html.

Gerber, Julien-François. 2014. "The role of rural indebtedness in the evolution of capitalism." Journal of Peasant Studies 41 (5): 1-19.

Gilens, Martin, and Benjamin I. Page. 2014. “Testing theories of American politics: Elites, interest groups, and average citizens." Perspective on Politics 12 (3): 564-581.

Glover, Richard. 2010. "The financialization of social life and the socialization of finance: Reviewing the concepts and the literature." Richard Glover (blog). https://richardrglover.files .wordpress.com/2011/03/financialization-ofsocial-life-and-the-socialization-of-finance-2010 .pdf.

Gordon, Colin. 2016. "Growing apart: A political history of American inequality." Inequality.org, last updated 2 January. http://scalar.usc.edu/ works/growing-apart-a-political-history-ofamerican-inequality/wall-street-and-mainstreet-the-rise-of-finance.

Graeber, David. 2011. Debt: The first 5,000 years. Brooklyn, NY: Melville House.

Graeber, David. 2014. "The truth is out: Money is just an IOU, and the banks are rolling in it." Guardian, 18 March. http://www.theguardian .com/commentisfree/2014/mar/18/truthmoney-iou-bank-of-england-austerity.

Greenfeld, Liah. 2001. The spirit of capitalism: $\mathrm{Na}$ tionalism and economic growth. Cambridge, MA: Harvard University Press.

Harvey, David. 2004. "The 'new' imperialism: Accumulation by dispossession." Socialist Register 40: 63-87.

Harvey, David. 2005. A brief history of neoliberalism. Oxford: Oxford University Press.

Harvey, David. 2010. The enigma of capital: The crises of capitalism. Oxford: Oxford University Press.

Howard, James L. 2007. "U.S. timber production, trade, consumption, and price statistics 1965 to 2005." Research Paper FPL-RP-637. Madison, WI: US Department of Agriculture, Forest Service, Forest Products Laboratory. https://www .fs.usda.gov/treesearch/pubs/28972.

IFF (Institute of International Finance). 2018. “Global debt monitor-January 2018." https:// www.iif.com/publication/global-debt-monitor/ global-debt-monitor-january-2018. 
IMF (International Monetary Fund). 2016. World Economic Outlook: Subdued demand-Symptoms and remedies. Washington, DC: IMF. https:// www.imf.org/en/Publications/WEO/Issues/ 2016/12/31/Subdued-Demand-Symptoms-andRemedies.

IMF (International Monetary Fund). 2017. Global Financial Stability Report: Is growth at risk? Washington, DC: IMF. https://www.imf.org/ en/Publications/GFSR/Issues/2017/09/27/ global-financial-stability-report-october-2017.

Ingham, Geoffrey. 2004. The nature of money. Cambridge: Polity.

Irwin, Neil. 2014. "Welcome to the everything boom, or maybe the everything bubble." New York Times, 7 July. https://www.nytimes.com/2014/07/ 08/upshot/welcome-to-the-everything-boom-ormaybe-the-everything-bubble.html.

Jones, Charles. 2002. Introduction to economic growth. New York: W. W. Norton.

Kaiser, Robert G. 2010. So damn much money: The triumph of lobbying and the corrosion of American government. New York: Vintage.

Kindleberger, Charles P. 2000. Manias, panics, and crashes: A history of financial crises. 4th ed. Hoboken, NJ: John Wiley and Sons.

Korten, David C. 1995. When corporations rule the world. Bloomfield, CT: Kumarian Press.

Kuhner, Timothy K. 2014. Capitalism v. Democracy: Money in politics and the free market constitution. Stanford, CA: Stanford Law Books.

Kumhof, Michael, and Jaromir Benes. 2012. "The Chicago Plan revisited.” Working paper no. 12/ 202. Washington, DC: International Monetary Fund. https://doi.org/10.5089/9781475505528 .001 .

Lewis, W. Arthur. 1965. Theory of economic growth. New York: Harper Torchbooks.

Lietaer, Bernard, and Jacqui Dunne. 2013. Rethinking money: How new currencies turn scarcity into prosperity. San Francisco: Berrett-Koehler Publishers.

Mahmud, Tayyad. 2013. "Debt and discipline: Neoliberal political economy and the working class." Kentucky Law Journal 101 (1): 1-54.

Milanovic, Branko. 2016. Global inequality: A new approach for the age of globalization. Cambridge, MA: Belknap Press.

Mishan, Erza J. 1967. The costs of economic growth. London: Pelican.
Moyer, Liz. 2016. "Argentina's debt settlement ends 15-year battle." New York Times, 29 February. https://www.nytimes.com/2016/03/01/business/ dealbook/argentinas-debt-settlement-ends-15year-battle.html.

Nietzsche, Friedrich. 2006. On the genealogy of morality. 2nd ed. Ed. Keith Ansell-Pearson. Trans. Carol Diethe. Cambridge: Cambridge University Press.

Noah, Timothy. 2012. The great divergence: America's growing inequality crisis and what we can do about it. London: Bloomsbury Press.

OECD (Organisation for Economic Co-operation and Development). 2014. Pension markets in focus. Paris: OECD. http://www.oecd.org/daf/fin/ private-pensions/Pension-Markets-in-Focus2014.pdf.

Phillips, Ronnie J. 1999. “The 'Chicago Plan' and New Deal banking reform." Working paper no. 76. Annandale-on-Hudson, NY: Levy Economics Institute of Bard College. https://doi.org/10.2139/ ssrn.160989.

Piketty, Thomas. 2014. Capital in the twenty-first century. Cambridge, MA: Belknap Press.

Reinhart, Carmen M., and Kenneth S. Rogoff. 2009. This time is different: Eight centuries of financial folly. Princeton, NJ: Princeton University Press.

Ro, Sam. 2015. "Here's what the $\$ 294$ trillion market of global financial assets looks like." Business Insider, 11 February. http://www.businessinsider. com/global-financial-assets-2015-2.

Robbins, Richard H., and Rachel Dowty. 2018. Global problems and the culture of capitalism. 7th ed. New York: Pearson Publishing.

Schmidt, Michael S. 2010. "New exotic investment: Latin baseball futures." New York Times, 17 November. http://www.nytimes.com/2010/11/18/ sports/baseball/18investors.html.

Scitovsky, Tibor. 1976. The joyless economy: The psychology of human satisfaction. Oxford: Oxford University Press.

Speth, James Gustave. 2008. The bridge at the end of the world: Capitalism, the environment and crossing from crisis to sustainability. New Haven, CT: Yale University Press.

Tcherneva, Pavlina R. 2014 "Reorienting fiscal policy: A bottom-up approach." Journal of Post-Keynesian Economics 37 (1): 43-66.

TPC (Tax Policy Center). 2017. "Amount of revenue by source." 17 February. http://www.taxpolicy center.org/statistics/amount-revenue-source. 
Trisi, Danilo. 2014. "Income inequality remains at historic high, census data shows." Center on Budget and Policy Priorities, 18 September. https://www.cbpp.org/blog/income-inequalityremains-at-historic-high-census-data-show.

Unionstat. 2017. "Union membership, coverage, density and employment, 1973-2017." http:// www.unionstats.com.

Vries, Jan de, and Ad van der Woude. 1997. The first modern economy: Success, failure, and perseverance of the Dutch economy, 1500-1815. Cambridge: Cambridge University Press.

WBG (World Bank Group). 2018. "Interest payments (current LCU).” Accessed 9 May. https://data .worldbank.org/indicator/GC.XPN.INTP.CN.

Wennerlind, Carl. 2011. The casualties of credit: The English financial revolution, 1620-1720. Cambridge, MA: Harvard University Press.

Werner, Richard A. 2014a. "Can banks individually create money out of nothing? The theories and the empirical evidence." International Review of Financial Analysis 36: 1-19.

Werner, Richard A. 2014b. "How do banks create money, and why can other firms not do the same? An explanation for the coexistence of lending and deposit-taking." International Review of Financial Analysis 36: 71-77.

Wolff, Edward. 2012. "The asset price meltdown and the wealth of the middle class." Working paper no. 18559. Cambridge, MA: National Bureau of Economic Research. https://doi.org/10.3386/ w18559.

Wolff, Edward N. 2013. "The asset price meltdown and the wealth of the middle class." Journal of Economic Issues 47 (2): 333-342.

Zarlenga, Stephen A. 2002. Lost science of money: The mythology of money, the story of power. Valatie, NY: American Monetary Institute.

Zepezauer, Mark, and Arthur Naiman. 1996. Take the rich off welfare. Tucson, AZ: Odonian Press. 